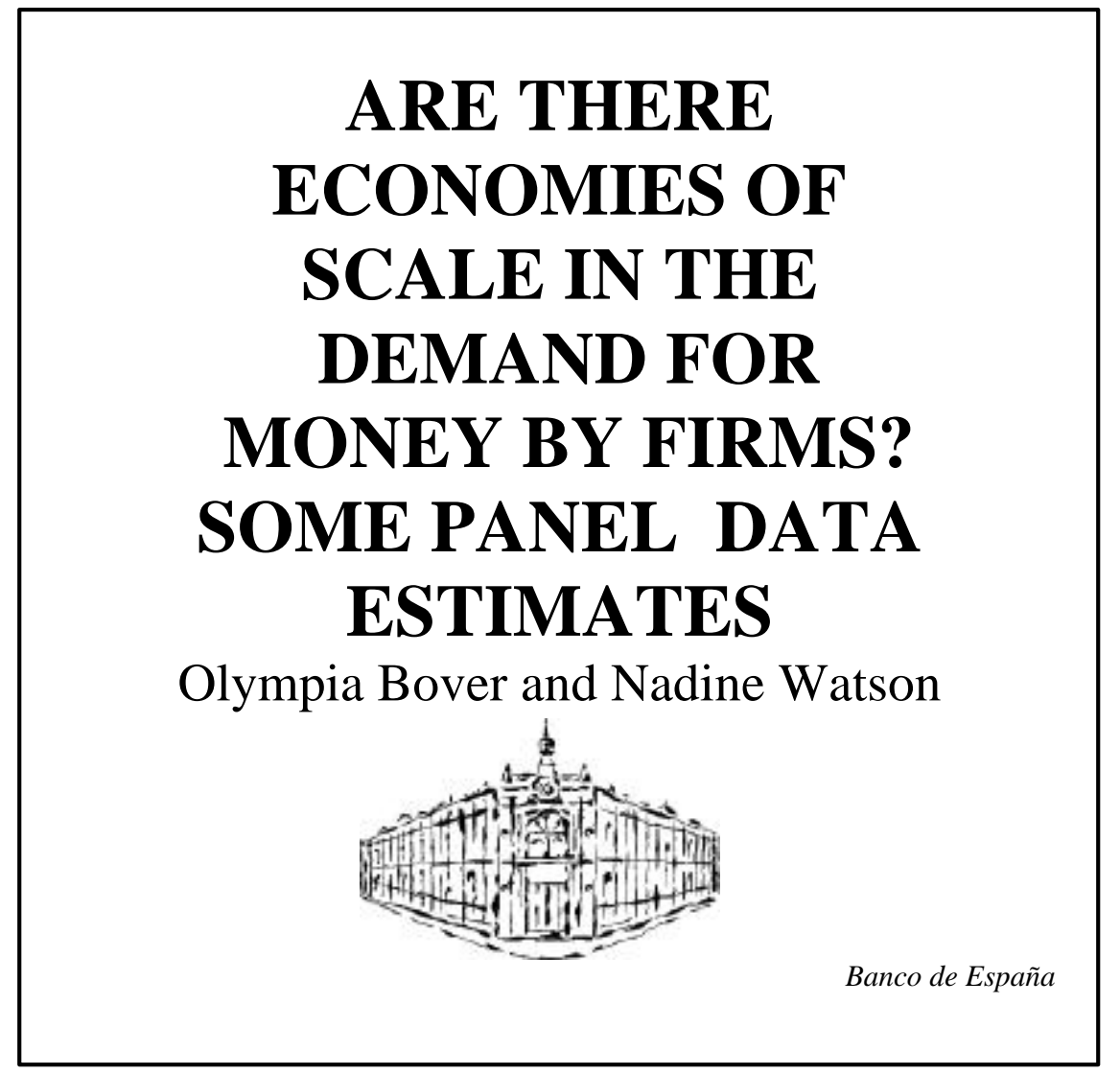

Banco de España - Servicio de Estudios

Documento de Trabajo n. ${ }^{\circ} 0008$ 


\title{
Are There Economies of Scale in the Demand for Money by Firms? Some Panel Data Estimates
}

\author{
Olympia Bover and Nadine Watson \\ Banco de España NERA
}

First version: December 1999

This version: 16 June 2000

\footnotetext{
* This paper was started during N. Watson's stay at Banco de España as a Research Fellow. We are very grateful to Manuel Arellano, Orazio Attanasio, Andrew Benito, Richard Blundell, Martin Browning, Steve Davies, José Luis Escrivá, Costas Meghir, Federico Sáez, and Teresa Sastre for helpful comments, to Nick Bloom and Steve Bond for providing the Datastream data, and to Chris Trengove for his help with Compustat.
} 


\begin{abstract}
The purpose of this paper is to estimate elasticities of scale in the demand for money by firms using firm level panel data. In common with the recent literature, we use disaggregate data to overcome the identification problems in aggregate time series approaches. Our main dataset is a sample of Spanish companies that are observed for the period 1983-1996, although we also analyse comparable datasets for the UK and the US. As measures of scale we consider both firm sales and firm output.

We find that the errors in the money demand equations contain two terms that are correlated with sales. Firstly, a permanent firm effect that may capture differences in managerial efficiency, efficiency wages, technological sophistication. Secondly, a measurement error in sales, probably due to the fact that cash holdings are end-ofperiod whereas sales are annual measures. We show that failure to control for these correlated unobservable terms results in important biases in the estimated sales elasticities.

The sale elasticity estimates from the Spanish sample increase from 0.6 to 0.99 when correlated fixed effects and measurement error are jointly considered. In addition, our estimates indicate declining sales elasticity from the mid-1980's to mid 1990's, a period of increasing financial innovations. This result suggests that financial innovations tend to reduce money demand mainly by reducing the sales elasticity. For the US and the UK we find constant sales elasticities over the period considered with values of 0.71 for the US and 0.96 for the UK.
\end{abstract}

While the main focus of the paper is the estimation of sales elasticities we also estimate interest rate elasticities of the demand for money, using both aggregate and firm specific interest rates. 


\section{INTRODUCTION}

The relation between the demand for money balances and its determinants is a key element in most theories of macroeconomic behaviour. In addition, the demand for money is a critical component in the formulation of monetary policy. Although interest rate intervention is monetary policy's main instrument to achieve price stability, monetary aggregates continue to be an important intermediary target used to gauge the stance of monetary policy. For years the stability of money demand equations has been an important area of research among central bankers. Not surprisingly, numerous estimates of money demand equations using different databases, different estimation techniques, for different countries and different time periods can be found in the literature. Scale elasticity measures vary considerably both empirically and theoretically, from one half or less in the case of Baumol - Tobin transactions demand models to those more in line with cash-in-advance models with elasticities near one or those greater than one. ${ }^{1}$

The most recent attempts to determine the elasticities of scale and stability of money demand functions involve the use of cross-sectional data, at regional, household and firm levels. ${ }^{2}$ This move has been prompted both as an attempt to resolve the identification problem inherent in aggregate analysis and to correct for biases in time series estimates arising from the correlation between technological innovation through time and the scale variables. Faig (1989) uses seasonal fluctuations in income to identify the income elasticity under the assumption that money demand functions do not shift over seasons. The author finds sales elasticities much lower than one. Mulligan and Sala-i-Martin (1992) assume that cross-state differences in income are not correlated with state specific shifts in the money-demand function. Using U.S. state cross-section data they obtain income elasticities between 1.3 and 1.5. Mulligan (1997) uses firm data and assumes that financial innovations are constant across firms within the same industry. His estimated elasticity of cash balances with respect to sales is close to 0.8. Mulligan and Sala-i-Martin (1996) look at a cross-section of households to estimate the interest rate elasticity of money demand. They find a very small elasticity. In addition their results show that the probability of households holding any amount of interest bearing assets is positively related to the level of financial assets while the cost of adopting financial technologies is positively related to age. Finally,

\footnotetext{
${ }^{1}$ To mention a few Friedman (1959), Meltzer (1963a, 1963b), Vogel and Maddala (1967), Miller and Orr(1966), Laidler (1985), Lucas (1988), Mulligan and Sala-i-Martin (1992) and Mulligan (1997). For estimates for Spain, see Cabrero et al. (1993) and references therein.
} 
Attanasio et al. (1998) using Italian household data for which financial sophistication is proxied by ownership of ATM cards, obtain an estimated elasticity of money demand with respect to consumption of 0.35 in the case of individuals who own ATM cards and 0.44 for those less sophisticated financially.

The use of individual data, aside from resolving the identification problem and time series bias, allows unobservable factors affecting money demand to be taken explicitly into account. Aggregate data is hard to interpret as it synthesises the behaviour of agents with very different money demand functions. Not only does the cost of cash management differ across agents according to their financial sophistication but also the opportunity cost of not having liquidity due to varying degrees of access to capital markets. The differences arise not only between households and firms but within each type of agent. In the context of the European union and the euro zone, the difficulty of interpreting aggregate money demand equations is especially relevant. Aggregate euro zone money demand is made up of individual country demands each with its particular distribution among households and firms and large and small agents. Reliable estimates of money demand parameters, based on micro-foundations and which take into account possible endogeneity of variables, measurement error and dynamics is of utmost important in interpreting aggregate results.

Theoretically to obtain a complete understanding of money demand parameters underlying aggregate estimates, one needs to estimate both household and firm equations. In Spain, according to the Cuentas Financieras for 1997, 33\% of M1 is in the hands of firms while the rest is in the hands of households. These figures would indicate that household demand drives the aggregate. However one must note that the figure for households is obtained as a residual and includes all non-profit institutions as well as singled owned firms which in Spain make up approximately $50 \%$ of total firms. ${ }^{3}$ Moreover, given that firms are financially more sophisticated than households, the potential importance of firm behaviour within the aggregate is all but negligible. ${ }^{4}$

In this paper we start by estimating a firm money demand equation in the vein of Mulligan (1997) for the period 1983-1996 using data from the Central de Balances del Banco de España (CBBE). We then test for the presence of firm specific effects, measurement error and feedback from money demand to sales due to technological

\footnotetext{
${ }^{2}$ Meltzer (1963a) was one of the first to use firm level data. However, the bulk of money demand estimates have been based on aggregate data.

${ }^{3}$ Directorio Central de Empresas, INE, 1998.

${ }^{4}$ In the US Flow of Funds data estimate cash in hands of households by residual leading to results very similar to those in Spain - a greater percent of total cash is in hands of households. However, when the Survey of Demand Deposit Ownership is used, non-financial firms appear to have over 50\% more cash than households.
} 
innovations. The presence of these factors, jointly or separately, would induce biases in the sales elasticity estimates. Firm specific effects on cash holdings may arise as a result of within-industry variation in productions functions across firms which are likely to be correlated with the firm's size and sales volume. ${ }^{5}$ Furthermore, measurement error is plausible due not only to inaccurate measurement of sales (as for example, the usual rounding off that takes place in firms datasets) but also to the possibility that the observed end of the period sales measure does not correspond exactly to the information firms use when deciding cash holdings. Finally, sales may be endogenous or predetermined due to simultaneity or feedback from technological shocks, affecting the demand for money by the firm and its future sales as well.

Reestimating the model using instrumental variable methods and testing for the presence of the above-mentioned factors, we fail to reject the presence of measurement error and correlated firm specific effects. This is shown to be true as well using US and UK firm data from Compustat and Datastream. For Spain, estimates of the sales elasticity for the beginning of the period increase from 0.6 to 0.99 when correlated fixed effects and measurement error are jointly considered. Thus taking into account both factors, firm specific effects and measurement error, we cannot reject the hypothesis of constant returns to scale at the beginning of the sample period. In addition, our estimates indicate declining sales elasticity from the mid-1980's to mid 1990 's, a period of increasing financial innovations. This result suggests that financial innovations tend to reduce money demand mainly by reducing the sales elasticity. For the US and the UK we find constant sales elasticities over the period considered, namely 0.74 for the US and 0.96 for the UK.

While the main focus of the paper is the estimation of sales elasticity we also estimate the interest rate elasticity of demand for money. Elasticities to aggregate interest rates are harder to pinpoint using firm level data due to the importance of the time series variation. Results show an average interest rate elasticity of around $1 / 3$ for the aggregate interest rate but the empirical model is not entirely satisfactory in this case. Using firm specific interest rates we find an elasticity of 0.08 . In addition we find that the impact of changes in the aggregate interest rates on money demand decreases for financially sophisticated firms.

The paper is organised as follows. In the second section the theoretical framework is described followed in section three by the description of the data used. The empirical model used to estimate the sales elasticity and our findings are

\footnotetext{
5 Alternatively, following Vogel and Maddala (1965) firm specific effects may capture varying opportunity costs of holding money across firms which may also be correlated with firm size. According
} 
described in section four. Finally in section five we provide comparable estimates for the US and the UK.

\section{THEORETICAL FRAMEWORK}

In the spirit of Baumol (1952) and Tobin (1956) models we consider that firms require cash to carry out transactions. Following Mulligan (1997b) we start with a production function of the form:

$$
y_{i t}=\left[(1-\lambda) F_{i t}\left(x_{i t}\right)^{\frac{\gamma-c}{\gamma}}+\lambda\left(\frac{\gamma-c}{\gamma-1}\right) T_{i t}^{\frac{\gamma-1}{\gamma}}\right]^{\frac{\gamma}{\gamma-c}}
$$

where $T_{i t}$ are transactions services specified as:

$$
T_{i t}=A_{i t} m_{i t}^{a} l_{i t}^{b}
$$

$x_{i t}$ is a composite input, $l_{i t}$ is the type of labour employed in transaction services, $m_{i t}$ is real money balances, and $A_{i t}$ denotes the firm's financial sophistication. The specification for $T_{i t}$ can be easily generalized to a CES, but this has no impact on the empirical content of the model. $\gamma$ is the elasticity of substitution between the composite input and the transaction services. If they are complements we may expect $\gamma<1$. Indeed we would expect $\gamma$ to be close to zero. Taking $\gamma \rightarrow 0$ as a limiting case we obtain a generalized Leontief production function

$$
y_{i t}=\min \left(F_{i t}\left(x_{i t}\right), T_{i t}^{1 / c}\right)
$$

Note that we allow through the parameter $c$ for certain economies of scales in transactions so that they may increase less than proportionately with output.

The cost minimizing demand for money is obtained by:

$$
\min _{x, l, m} p_{i t} x_{i t}+w_{i t} l_{i t}+R_{i t} m_{i t}
$$

subject to the production function. The variable $R_{i t}$ is the nominal opportunity cost of money, $p_{i t}$ is the price of the composite input, and $w_{i t}$ is the wage of the workers involved in the production of transaction services.

Mulligan (1997b) minimizes cost subject to (2.1) and provides an approximate money demand equation for $\lambda \rightarrow 0$. Doing cost minimization subject to (2.1') (ie. $\gamma \rightarrow 0$ )

to Bealy and Myers (1996), for very large firms the transaction costs of buying or selling securities becomes trivial compared to the opportunity cost of holding idle cash balances. 
we obtain a similar equation in terms of empirical implications (assuming $\gamma \rightarrow 0$ renders the approximation $\lambda \rightarrow 0$ unnecessary).

Rewriting the cost minimization problem we obtain

$$
\min _{m} p_{i t} F_{i t}^{-1}\left(y_{i t}\right)+m_{i t} R_{i t}+y_{i t}^{c / b} A_{i t}^{-1 / b} m_{i t}^{-a / b} w_{i t}
$$

The relevant first order condition is

$$
R_{i t}-(a / b) y_{i t}^{c / b} A_{i t}^{-1 / b} m_{i t}^{-(a+b) / b} w_{i t}=0
$$

which gives the conditional demand function for money

$$
m_{i t}=\left[\left(R_{i t} / w_{i t}\right)(b / a) A_{i t}^{1 / b} y_{i t}^{-c / b}\right]^{-b /(a+b)}
$$

Note that the money demand function derived here assuming a Leontief production function in the composite input and in transaction services is the same as one derived from a cash-in-advance model where money does not enter the production function but is assumed to be needed by firms proportionately to their output (see Feenstra, 1986, Fisher, 1974, and Fujiki and Mulligan, 1996).

After taking logs to both sides of equation (2.6) we obtain the money demand equation which will be the focus of our empirical analysis:

$$
\log m_{i t}=\left(\frac{c}{a+b}\right) \log y_{i t}-\left(\frac{b}{a+b}\right) \log R_{i t}+\left(\frac{b}{a+b}\right) \log w_{i t}-\left(\frac{b}{a+b}\right) \log \left(\psi_{i t}\right)
$$

where $\psi_{i t}=(b / a) A_{i t}^{1 / b}$. The term $A_{i t}$ may be specified as $A_{i t}=A_{t} H_{i} V_{i t}$ where $A_{t}$ is a time effect, $H_{i}$ is a firm effect, and $V_{i t}$ is a firm's specific shock at period $t$. Note that sales may be correlated with the components of $A_{i t}$ through the production function.

Note that in the empirical model $H_{i}$ need not be the only component of the firm's individual effect. Suppose that due to some form of inefficiency a firm's observed output is permanently below its production frontier over the sample period. In such case, the individual effect will also contain a measure of the production inefficiency gap, which unlike $H_{i}$ will be negatively correlated with observed sales.

It could be of interest to model $A_{i t}$ using a theory that emphasises the degree of lack of synchronisation between cash receipts and payments, as in the model of Miller and Orr (1966) who find a relationship between long run demand for money and the variability of cash flows. However here, since the focus is on measuring economies of scale in the demand for money, we control for heterogeneity in financial sophistication or lack of synchronisation of that sort without modelling them by using panel data and allowing for fixed and time effects. 
In addition, we will allow for the level of transactions to be related to the take up of financial innovations across the economy by allowing $c$ to vary over time. If for example only a few firms accept credit cards, the firm's financial sophistication will decrease the number of transactions less than if all firms accept them. The adoption of IT technologies in the procurement process is another example of the importance of widespread adoption of the innovation before it can reduce the number of transactions. The take up of new technological innovations which reduce the required number of transactions increases over time due to the existence of network effects, as more firms adopt the new technology less firms can afford not to do so.

Note that the coefficient on sales can be different from one, even if $c=1$, if $a+b \neq 1$ which will happen if there are non-constant returns to scale in the production of transaction services.

\section{DATA}

The firm-level data in this study were obtained from the Central Balance Sheet Office of the Bank of Spain. The initial database included 18,814 firms over the 19831996 period. The main advantage of using this database is that it contains detailed annual income and balance sheet information for non-financial firms in a wide range of sectors. Aside from its periodicity, the main limitation of the CBBE database is the significant weight of large-sized firms, public sector companies, electric utilities and, in general, firms with a large volume of fixed assets. ${ }^{6}$

\subsection{Selection Criteria}

Only firms with positive sales and cash are included in the sample used for estimation. Furthermore, due to the estimation methods used only firms with at least four consecutive observations are kept in the sample, reducing the number of firmyears from 91,119 to 23,749 (corresponding to 5,649 firms). In addition, to estimate the interest rate elasticity only observations with positive interest rates and wages are kept.

Rather than concentrating only on manufacturing firms, the sample contains firms in all nonfinancial sectors. Coverage of Spanish sectoral production by the CBBE database however is greatest for water and electricity utilities, transport,

\footnotetext{
${ }^{6}$ In $1994,77 \%$ of the sample's gross value added originated in 434 firms with more than 500 workers. In the same year, $37 \%$ of the sample's gross valued added corresponded to 392 publicly owned firms and $83 \%$ of total workers were permanent.
} 
communications and manufacturing. ${ }^{7}$ Table A. 1 presents the sectoral decomposition of the data. Total manufacturing represents close to $50 \%$ of the sample. However, other sectors also have high individual sample representation - trade (23\% in 1996), real estate (11\% in 1996) and construction (7\% in 1996). Over the whole sample period the main variations in sectoral composition are observed in manufacturing and real estate: the percentage of manufacturing firms has decreased nearly 20 percentage points while the percentage of real estate and other services firms has more than doubled. ${ }^{8}$

Roughly $70 \%$ of the sample corresponds to small firms with less than 100 employees while large firms with over 500 employees represent approximately $7 \%$ of the sample. These percentages have varied slightly over time with small firms increasing by 7 percentage point between 1986 and 1996 while medium size firms have decreased by 6 percentage points (see Table A.2). This relative increase of small sized firms in the sample corresponds to a similar tendency observed for the total of Spanish firms although it has been much more pronounced for the total than in the sample. $^{9}$ The percentage of public firms ${ }^{10}$ in the sample has remained stable throughout at approximately $6 \%$.

\subsection{Definition of Variables ${ }^{11}$}

In order to estimate the elasticity of cash holdings by firms, the money variable must include any immediately negotiable medium of exchange. From the balance sheets of the Central de Balances we use the sum of cash, demand deposits and savings deposits as our variable for cash holdings. ${ }^{12}$ Sales, which we use as our measure of production, are directly identified from the balance sheets and both sales and money are deflated by the aggregate GDP deflator (1986 base). Other firm level

\footnotetext{
${ }^{7}$ Sector Percentage of the Total Sectoral Value Added in CBBE Sample

-Prod. and Dist. of Elect., Gas and Water $\quad 97.0 \%$

-Transp. and Communications $\quad 59.4 \%$

-Manufacturing Industry $\quad 33.4 \%$

-Extraction Industry $\quad$. $\quad 23.7 \%$

-Construction $\quad 13.5 \%$

-Trade $12.0 \%$

-Others $4.1 \%$

${ }^{8}$ Note that while the average sales/cash ratio for manufacturing firms is 58.7 , real estate and other services has one of the lowest ratios, 15.6.

${ }^{9}$ According to Directorio Central de Empresas, INE, 1998 figures, the increase in the percentage of small firms (less than 100 employees) began in the last decade. In 1989 small firms made up $20 \%$ of total firms. In 1996 this percentage increased to nearly $44 \%$.

${ }^{10}$ Defined by the CBBE as those firms with over $50 \%$ of their capital stock owned by the Public Sector, or, alternatively, those firms known to be controlled by the Public Sector.

${ }^{11}$ Summary statistics in our sample of the variables used can be found in Table A.3.

${ }^{12}$ The reason for including the latter is that from 1992, only the total for demand and savings deposits is available for firms with less than 100 workers.
} 
variables used are interest rates, wages and a proxy for financial sophistication. The firm level interest rate is defined as the payments on credit received divided by external financing subtracting lease interest rates already included in the debt variable. Firm wage level was calculated dividing total wages ${ }^{13}$ by total employees. Finally we have constructed a variable to measure the firm's financial sophistication to capture the differential impact of aggregate interest rates on firm's cash holding decisions. The proxy used for financial sophistication is the percentage of non-bank debt to total debt. In addition to the firm level data, we use aggregate data for economic sector wages and interest rates. The first are obtained from Estrada et al (1998) and the latter from the Bank of Spain. ${ }^{14}$ Two different aggregate interest rate variables are used, the composite aggregate $\mathrm{M} 2$ interest rate and the composite interest rate for $\mathrm{M} 2$ alternatives.

\section{EMPIRICAL ANALYSIS AND RESULTS ${ }^{15}$}

We started by estimating by OLS a firm money demand equation in the vein of Mulligan (1997).

$$
\log m_{i t}=\beta \log s_{i t}+\lambda_{t}+e_{j}+v_{i t}
$$

where $\lambda_{t}$ and $e_{j}$ are time and industry dummies respectively, and $v_{i t}$ is an error term. The time dummies capture the time component of $A_{i t}$ and the effect of non-firm specific aggregate interest rates, while for now we omit the term in $w_{i t}$. At the end of this section we will report our attempts to estimate the effect of interest rates and wages on money demand by introducing variables that try to measure them.

The results are reported in Table 1 column 1 . The sales elasticity seems to have been decreasing over time (as captured by interactions of log sales with trend and trend squared), as column 2 shows. We interpret this in the context of our model as reflecting that the effects of the increasing take up of financial innovations across the economy depend on the size of the firm. This is a sensible effect indicating that financial innovations tending to reduce money demand do so -at least in part- by reducing the sales elasticity. ${ }^{16}$

The positive sign and slow decline of the residual serial correlation coefficients (shown in Table A.4), together with the values of the first- and second-order serial

\footnotetext{
${ }^{13}$ Total sueldos y salarios.

${ }^{14}$ For a reference, see Cuenca (1994)

${ }^{15}$ All the estimations have been performed using the DPD98 program by Arellano and Bond (1998).

${ }^{16}$ From now on, terms in $\log$ sales interacted with trend and trend squared will be allowed for, although for clarity of exposition we will be referring to log sales in the equations.
} 
correlation test statistics, are consistent with the presence of firm specific effects, in spite of the inclusion of industry dummies in the estimated equation. Moreover, the first- and second-order serial correlation coefficients tend to be higher than the others, which suggests that, in addition to individual effects, the error term may contain a 'short memory'serially correlated component.

If sales are uncorrelated with the permanent and transitory components of the error term, the previous OLS estimates in levels will remain consistent although inefficient. However, if sales were uncorrelated with the transitory errors but correlated with the firm effects, we would expect OLS estimates in levels to be biased but not OLS estimates in first-differences or orthogonal deviations (Arellano and Bover, 1995). Firm specific effects on cash holdings may arise as a result of within-industry variation in production functions across firms. Moreover, these technological differences are likely to be correlated with firm's size and hence with firm's sales.

Also reported in Table 1 are OLS estimates in first differences (columns 3 and 4) and orthogonal deviations (columns 5 and 6). The value of the test statistics for second-order autocorrelation in the first-differenced residuals confirm the presence of first-order serial correlation in the transitory errors of the original model in levels. The sales elasticity estimated by OLS in first differences is almost half the size of that in levels. In itself, this discrepancy could be attributed to bias in the OLS levels estimate resulting from positive correlation between sales and firm effects. However, the fact that the orthogonal deviations estimate is not aligned with the one in first differences (but lies in between the estimate in levels and the latter), indicates that correlated effects alone cannot account for these results.

OLS estimates in first-differences and orthogonal deviations would be expected to be biased with negative biases of different magnitude if sales were subject to measurement error (Griliches and Hausman, 1987), but also if sales were predetermined or endogenous as opposed to strictly exogenous. For example, if log sales were measured with an error $\varepsilon_{i t}$, the asymptotic bias of the OLS estimate in first differences (abstracting from time dummies) would be given by

$$
\frac{-\beta \operatorname{Var}\left(\Delta \varepsilon_{i t}\right)}{\operatorname{Var}\left(\Delta \log s_{i t}\right)} \text {. }
$$

On the other hand, if sales were predetermined in the sense of being correlated with lagged, but not present and future, values of an innovation $v_{\text {it, }}$, the first-difference OLS bias would be of the form

$$
\frac{\operatorname{Cov}\left(\Delta \log s_{i t}, \Delta \mathrm{v}_{i t}\right)}{\operatorname{Var}\left(\Delta \log s_{i t}\right)}=\frac{-\operatorname{Cov}\left(\log s_{i t}, \mathrm{v}_{i t-1}\right)}{\operatorname{Var}\left(\Delta \log s_{i t}\right)} .
$$


Note that if sales were endogenous in the sense of being correlated with lagged and present, but not future, values of $v_{i t}$ the form of the bias will not particularise to the right-hand side of the expression above.

Measurement error bias may occur not only if sales are not accurately measured (for instance, rounding off is an usual practice in firms datasets ${ }^{17}$ ), but also if money demand does not respond to our observed measure of sales but rather to some related concept. For example, our sales variable is an annual measure, which may not correspond exactly to the information on sales that the firm takes into account when deciding its end of year cash holdings.

Finally, sales may be predetermined or endogenous due to feedback or simultaneity from technological shocks, having an effect on the demand for money by the firm and on its future sales as well despite having allowed for time and firm effects.

In what follows we describe the two types of models we have estimated under the alternative assumptions of measurement error and feedback, in both cases allowing for correlation between sales and firm effects. The presentation will also make clear the difficulties in identifying a model that combines these two features.

\subsection{The feedback model}

We begin by considering a model of the form

$$
\log m_{i t}=\beta \log s_{i t}+\lambda_{t}+\eta_{i}+v_{i t}
$$

where $\eta_{i}$ is a firm effect possibly correlated with sales. This correlation is expected to be negative if the firm effects reflect mainly differences in the firms financial sophistication or in firm specific production inefficiencies. However a positive correlation may arise if the firm effects reflect mainly differences in the wages paid to the managers involved in the cash holdings decisions and which have been omitted for now. We wish to allow for the possibility that sales are not only influenced by firm effects but also by lagged (or lagged and present) transitory shocks. Inspection of the residual auto-correlation matrix shown in Table A.4 suggested some transitory serial correlation in addition to fixed effects. To obtain consistent estimates therefore both components be must taken into account by differencing and using instrumental variables. If, for example, $v_{\text {it }}$ followed a second-order moving-average process, $\Delta v_{\text {it }}$ would be uncorrelated with predetermined (endogenous) sales and cash holdings lagged, respectively, three (four) and four periods or more. These lagged variables

\footnotetext{
${ }^{17}$ For example, the CBBE rounds off to the nearest million pesetas, and Compustat to the nearest thousand dollars.
} 
could thus be used as valid instruments for the equation in first differences in which firm effects have been differenced out.

However, with instruments lagged so many periods, the scale parameter is likely to be poorly identified. Because of this, we chose to explicitly model a process for $v_{\text {it }}$ and estimate its coefficients together with those in the money demand equation. Since for this purpose an autoregressive specification is more convenient, we assume an $\operatorname{AR}(2)$ model for $v_{\mathrm{it}}$ :

$$
v_{i t}=\rho_{1} v_{i t-1}+\rho_{2} v_{i t-2}+\zeta_{i t}
$$

where $\zeta_{i t}$ is a white noise error.

Substituting (4.2) into (4.3) and re-arranging terms, we obtain $\log m_{i t}=\rho_{1} \log m_{i t-1}+\rho_{2} \log m_{i t-2}+\beta \log s_{i t}-\beta \rho_{1} \log s_{i t-1}-\beta \rho_{2} \log s_{i t-2}+\lambda_{t}^{*}+\eta_{i}^{*}+\zeta_{i t}$

which is in the form of a dynamic regression model with non-linear common factor restrictions, where $\lambda_{t}^{*}=\lambda_{t}-\rho_{1} \lambda_{t-1}-\rho_{2} \lambda_{t-2}$ and $\eta_{i}^{*}=\left(1-\rho_{1}-\rho_{2}\right) \eta_{i}$.

The first differenced shock $\Delta \zeta_{\text {it }}$ will be orthogonal to $\left(\log m_{i 1}, \ldots, \log m_{i t-2}\right)$ and $\left(\log s_{i 1}, \ldots, \log s_{i t-2}\right)$ and also to $\log s_{i t-1}$ if sales are predetermined instead of endogenous. These orthogonality conditions can be exploited to estimate $\beta, \rho_{1}, \rho_{2}$ and the time dummy coefficients, either by non-linear GMM, or in two stages, as we have actually done; estimating first by linear GMM the unrestricted model, and enforcing the comfac restrictions in a second step by minimum-distance.

An alternative way of rationalizing the observed persistence in cash holdings net of firm effects, would be through a partial adjustment model for money demand or some other form of distributed lag effect of sales on cash holdings. Mulligan (1997) considered a distributed lag of sales as an approximation to some 'permanent sales' concept, to which firms might respond as opposed to current sales. However, in our data set augmenting the static model with lagged sales terms, and estimating the resulting equation in first-differences by either OLS or GMM, failed to account for the residual autocorrelation and the lagged sale effect turned out to be small and not statistically significant.

A partial adjustment model might fare empirically better (as it could just be an unrestricted version of equation (4.4)), but we do not regard an adjustment cost explanation to be particularly important a priori in the context of money demand. At least, not sufficiently so to wish to model all the observed serial correlation as a partial adjustment mechanism (for a similar opinion see McCallum and Goodfriend, 1987, and references therein). In any event, the common factor restrictions in (4.4) are testable, 
and we tested them as a by-product of our minimum-distance estimation procedure, not finding much evidence against the restrictions.

Note that in the context of the current model we can test whether sales are strictly exogenous as opposed to only a predetermined variable, since in the former case not only $\left(\log s_{i 1}, \ldots, \log s_{i t-1}\right)$ would be valid instruments for equation (4.4) in firstdifferences but also $\left(\log s_{i t}, \ldots, \log s_{i T}\right)$. Similarly, we could test for predeterminedness vs. endogeneity of sales by testing the validity of log $s_{i t-1}$ as an instrument for (4.4). Of course, if we believed in the strict exogeneity assumption, sales at all lags would be orthogonal to the first differenced errors from equation (4.2) regardless of their serial correlation properties, and there would be no need to model error autocorrelation.

Finally, if sales are measured with error, that is, if cash holdings respond to $\log s_{i t}^{*}$, but observed sales are given by

$$
\log s_{i t}=\log s_{i t}^{*}+\varepsilon_{i t}
$$

where $\varepsilon_{i t}$ is an uncorrelated measurement error term, the equation error in (4.4) will contain additional terms and take the form:

$$
\zeta_{i t}^{*}=\left(\zeta_{i t}-\beta \varepsilon_{i t}-\beta \rho_{1} \varepsilon_{i t-1}-\beta \rho_{2} \varepsilon_{i t-2}\right) .
$$

As a result, while $\Delta \zeta_{\mathrm{it}}$ remains uncorrelated to $\left(\log \mathrm{s}_{\mathrm{i} 1}, \ldots, \log \mathrm{s}_{\mathrm{it}-1}\right)$ in the predetermined case (or up to t-2 in the endogenous case), the actual first-differenced equation error $\Delta \zeta_{i t}^{*}$ will only be uncorrelated to $\left(\log \mathrm{s}_{\mathrm{i} 1}, \ldots, \log \mathrm{s}_{\mathrm{it}-4}\right)$. The latter are likely to be weak instruments, implying that the scale parameters may be poorly identified in this combined feedback with measurement error model.

In the first column of Table 2 we present GMM/MD estimates imposing the comfac restrictions and allowing for predetermined sales with white noise measurement errors. ${ }^{18}$ The comfac constraints are not rejected, nor does the Sargan test reject the validity of the overidentifying restrictions.

In the next three columns we present estimates that, ruling out measurement error, treat sales as an endogenous variable (column 2), a predetermined variable (column 3) or as a strictly exogenous variable (column 4). Note that the instrument sets used in columns 1 to 4 are nested in an ascending order of restrictiveness. We can therefore check the validity of various assumptions by looking for significant differences in parameter estimates (Hausman tests) or in minimized GMM criteria (incremental Sargan tests). These are reported in Table 2. First, as we can see by comparing columns 1 and 2, the Hausman and Sargan tests would not reject the absence of

\footnotetext{
18 A non-linear minimum distance routine written in Gauss enforces and tests the common factor restrictions from unrestricted (DPD) linear GMM estimates.
} 
measurement error, but there is a noticeable change in the magnitude of the leading sales coefficient. Second, if we compare columns 2, 3, and 4, the parameter estimates do not change much, the Sargan tests still accept the validity of the model, but the comfac tests get worse. Thus, there is some evidence against the validity of models without measurement error. In particular when lack of measurement error is combined with the strict exogeneity assumption (as in column 4). Finally, note that having allowed for a second-order autoregressive process leaves no signs of autocorrelation in the residuals.

\subsection{The measurement error model}

If we take as a maintained hypothesis the strict exogeneity of sales with respect to cash holdings shocks, the hypothesis of measurement error in sales can be more profitably explored, as we now explain.

Suppose that money demand responds to 'true' sales $s_{i t}^{*}$, firm and time effects, and technological shocks $v_{\text {it }}$, so that

$$
\log m_{i t}=\beta \log s_{i t}^{*}+\lambda_{t}+\eta_{i}+v_{i t}
$$

Here we assume that $s_{i t}^{*}$ is potentially correlated with the firm effects $\eta_{\text {i }}$, but it is uncorrelated to past, present and future shocks $v_{i t}$. We also assume that these shocks may be correlated in an arbitrary way. There is, however, a multiplicative measurement error in observed sales $\mathrm{s}_{\text {it }}$ such as, as above,

$$
\log s_{i t}=\log s_{i t}^{*}+\varepsilon_{i t}
$$

which implies:

$$
\log m_{i t}=\beta \log s_{i t}+\lambda_{t}+\eta_{i}+\left(v_{i t}-\beta \varepsilon_{i t}\right) .
$$

Thus, the error term in the relationship between cash-holdings and observed sales is made of two components: a measurement error in sales and a 'true' shock component.

Given strict exogeneity of sales relative to $v_{i t}$, the time series properties of $v_{\text {it }}$ and $\varepsilon_{i t}$ have very different implications for the identification of the sales elasticity. If $\varepsilon_{i t}$ is a white noise measurement error, then $\left(\log s_{i 1}, \ldots, \log s_{i-2}, \log s_{t+1}, \ldots, \log s_{i T}\right)$ are uncorrelated with $\left(\Delta v_{i t}-\beta \Delta \varepsilon_{i t}\right)$, regardless of the serial correlation in $v_{i t}$, and these orthogonality conditions can be used in estimating $\beta$ by GMM. If, on the other hand, the measurement error component $\varepsilon_{\text {it }}$ is arbitrarily serially correlated then no lags or leads of sales would be valid instruments for $\left(\Delta v_{i t}-\beta \Delta \varepsilon_{i t}\right)$. 
Here we allow for a white noise measurement error, and regard observed residual serial correlation as arising from autocorrelation in $v_{i t}$. We do not model such autocorrelation but we take it into account when calculating standard errors.

In column 2 of Table 3 we report estimates of such model. There is a very substantial difference in the magnitude of the estimated sales elasticity as compared with that in column 4 of Table 1. To make sure this is not an artefact of using a different estimation method, we report in column 1 of Table 3 a model estimated by GMM using all lags and leads of sales as instruments (which would be valid under strict exogeneity and no measurement error). As it can be seen, the results are very similar to the OLS results from column 4, Table 1.

The comparison between columns 1 and 2 in Table 3 shows evidence against the validity of $\log s_{i t-1}$ and $\log s_{i t}$ as instruments, from looking at both differences in parameter estimates and differences in Sargan statistics. The Sargan test for the estimated measurement error model in column 2 shows no evidence against the validity of the overidentifying restrictions (including the lead sales terms that are used as instruments). This is so in spite of the indication of second-order residual autocorrelation in the first differenced residuals, which is consistent with the assumption of serially correlated technological errors but uncorrelated measurement errors.

The estimated sales elasticity in this model is much higher than the one obtained when measurement error is ignored. These estimates would not reject the hypothesis of constant returns to scale during the mid-1980's with a tendency to move towards increasing returns to scale afterwards.

\subsection{Testing for lack of correlation between sales and firm effects}

The previous estimates allowed for correlation between sales and the unobserved firm specific effect using orthogonal deviations or a first difference transformation of the data. However, it is worth testing whether sales are correlated with the firm effects because in the absence of such correlation estimates of the model using moment conditions in levels would be valid.

We tested this hypothesis in two ways. Firstly, we estimated a measurement error model in levels, allowing for a white noise measurement error in sales (that is, using $\log s_{i 1}, \ldots, \log s_{i t-1}, \log s_{i t+1}, \ldots, \log s_{i T}$ as instruments). The results are reported in column 3 of Table 3. The Sargan test strongly rejects the null hypothesis of absence of correlation. 
Secondly, we tested for uncorrelated firm effects in the context of the models with common factor restrictions. To do so, we calculated a 'system' GMM estimator (see Arellano and Bover, 1995), based on the following orthogonality conditions:

$$
\begin{aligned}
& E\left[\left(\log m_{i 1}, \ldots, \log m_{i t-2}, \log s_{i 1}, \ldots, \log s_{i T}\right) \Delta \zeta_{i t}\right]=0, \\
& E\left[\log s_{i t}\left(\eta_{i}^{*}+\zeta_{i t}\right)\right]=0 \quad(\mathrm{t}=3, \ldots, \mathrm{T}) .
\end{aligned}
$$

where $\zeta_{i t}$ and $\eta_{i}^{*}$ are as introduced in equation (4.4). The results are reported in Table 2, column 5 .

GMM estimates exclusively based on the first-difference orthogonality conditions (4.5) are reported in Table 2, column 4. These orthogonality conditions are valid whether log sales are correlated with firm effects or not, provided they are strictly exogenous relative to $\zeta_{i t}$. However, if log sales are uncorrelated to $\eta_{i}^{*}$, the level moment conditions (4.6) will also be valid. Therefore the incremental Sargan test resulting from the comparison of the estimates in columns 4 and 6 , which tests the validity of (4.6), can be regarded as a test of uncorrelated firm effects. ${ }^{19}$ As can be seen from the table, this test rejects the suitability of the additional instruments for the errors in levels, and hence also the absence of correlation between sales and firm effects.

\subsection{Assessment}

The results found thus far are summarized in Table 4. From the comfac models that allowed for predetermined sales, we found some evidence of measurement error coming, firstly, from the change in estimated sales coefficients, and, secondly, from the worsening of comfac restriction tests (see Table 2).

The remaining puzzle, however, is the substantial difference between the sale elasticities estimated from the measurement error model and the comfac model. One candidate explanation for the much lower estimate in the comfac model would be the possibility that the GMM estimates in the presence of lagged dependent variables suffer from small sample bias, despite our sample size being quite reasonable. To check for this possibility we used an 'Anderson-Hsiao type' of estimator since the estimation of this just-identified equation relies on a minimal number of moments. From the results (column 5, Table 2) we could see that our GMM method might be

\footnotetext{
${ }^{19}$ Note that the orthogonality conditions (4.5) and (4.6) are equivalent to:

$E\left[\left(\log m_{i 1}, \ldots, \log m_{i t-2}\right) \Delta \zeta_{i t}\right]=0$

$E\left[\left(\log s_{i 1}, \ldots, \log s_{i T}\right)\left(\eta_{i}^{*}+\zeta_{i t}\right)\right]=0$.
} 
responsible for some downward bias in the estimation of the comfac model but there is a much larger difference to be accounted for.

Another potential source of bias in the comfac model is the possibility that the autoregressive coefficients $\rho_{1}$ and $\rho_{2}$ are heterogeneous across firms. In the case of heterogeneous dynamics, we would not be getting consistent estimates of average $\rho_{1}$, $\rho_{2}$, nor of the elasticity of sales in the model containing lags of the dependent variable (see Pesaran and Smith, 1997). The estimation of the static measurement error model would in this case provide a more reliable estimate of sales elasticity. Note that, in the absence of truly exogenous instruments, there might be a trade-off here between the two types of models. On the one hand, static models will be robust to heterogeneous dynamic responses and will allow for measurement error but not for predetermined variables among the regressors. On the other hand, models that specify the serial correlation pattern and allow for predetermined variables might be subject to biases if there is heterogeneity in the response to lagged shocks (or the serial correlation process is otherwise misspecified), and will be more difficult to identify in the presence of measurement errors.

Thus, the model in the second column of Table 3 should not be viewed as a special case of the model in the first column of Table 2. The latter allows for predetermined sales but at the expense of reliance on an auxiliary assumption about the form of serial correlation (risking biases if this auxiliary assumption turns out to be false). The former gives valid estimates under white noise measurement error and serial correlation of an arbitrary form, but it requires strict exogeneity as a maintained assumption.

In our case we tend to believe that given individual and time effects a priori our sales variable is not very likely to be affected by unanticipated shocks to the firm's money demand (and is therefore likely to be strictly exogenous), but it may contain a non-negligible measurement error, specially in first differences. Furthermore, we found no evidence against the measurement error model. We are therefore more inclined to believe the estimates obtained from the model in column 2 of Table 3.

By comparing column 2 in Table 1 with columns 1, 2, and 3 in Table 3, it is clear that it is the fact that we have taken into account both the existing correlation of sales with the firm specific effect and the presence of measurement errors for sales that makes us accept the hypothesis of constant returns to scale prevailing at the beginning of our sample period. 


\subsection{Relation to other estimates of sale elasticities in the literature}

As we have seen in the previous section, by taking into account both the existing correlation of sales with the firm specific effect and the presence of measurement errors in sales, we cannot reject the hypothesis of constant returns to scale at the beginning of our sample period. Our estimates also indicate that the sales elasticity seems to have been decreasing from the mid 1980's to the mid 1990's probably indicating that financial innovations tending to reduce money demand do so mainly by reducing the sales elasticity. Indeed, after allowing for this time varying sales elasticity any negative additive trend in the levels disappears.

In Table 1 we also reported estimates of the sales elasticity without considering at the same time correlated fixed effects and measurement errors. The estimated sales elasticities under those circumstances are much lower and very much in line with the results obtained in the literature using firm data. Mulligan (1997) reports a sales coefficient of around 0.8 to be compared to our 0.6 in Table 1 column 1 . However, Mulligan (1997b) using a larger sample that includes smaller firms (including those with sales less than $\$ 1$ million in 1987 dollars), obtains cross-sectional sales elasticities for the period after the mid 1980's very similar to our 0.6. More recently, Adao and Mata (1999) using a Portuguese sample of firms similar to ours report an estimated sales elasticity of around 0.5 . In no case the hypothesis of constant returns to scale is accepted in those papers ${ }^{20}$.

These estimates may be biased because they have not taken into account the possibility that unobserved differences in the way firms operate may be correlated with the level of sales, and that, at the same time, sales may be an error-ridden measure of the relevant scale variable in a firm money demand equation. Aside from being sensible a priori reasons for these to be present, our various tests and estimations in the previous section seem to confirm their presence. In section 5 we pursue this by providing some comparable results from US and UK firm panel data.

\footnotetext{
${ }^{20}$ Mulligan $(1997,1997 b)$ uses a more narrow definition of money (Compustat's Cash variable) while Adao and Mata (1999) variable is defined in the same way as ours.
} 


\subsection{Estimating interest rate elasticities}

While the main focus of the paper is the estimation of the sales elasticity of the demand for money, another very relevant parameter is the interest rate elasticity of the demand for money. Aggregate interest rate elasticities are more difficult to pin down with firm data due to the importance in this case of time series variation. In Table 5 we report some results of our attempts to estimate it.

In the first column of Table 5 we reproduce our preferred specification of Table 3 column 2 . In the second column we introduce as our interest rate variable the aggregate composite interest rate for $\mathrm{M} 2$ alternatives in nominal terms. The problem is that when we remove the time dummies that capture other common macroeconomic influences aside from the aggregate interest rate, the specification worsens significantly, as the Sargan test shows. However the main conclusions with respect to the other coefficients would not vary. We allowed for a trend in the levels but its exclusion does not affect the results.

We also tried the differential between the $\mathrm{M} 2$ interest rate and the interest rate of the M2 alternatives and the results are unchanged. Furthermore, since in the theoretical model the interest rate is relative to wages but these are not included in the equation, we have also estimated the model using the real interest rate. The results were almost identical indicating that probably the nominal changes in interest rates dominated during our sample period.

In column 3 we allow the interest rate elasticity to vary according to the degree of financial sophistication of the firm and for that we introduce an interaction of the aggregate interest rate and the percentage of non-bank debt of the firm. The estimated effect indicates that more financially sophisticated firms are less sensitive to the aggregate interest rate.

In the last column we have used a measure of firm specific interest rates. Note that the variable used represents an average interest rate for the firm rather than a marginal one. Therefore, since part of the individual variation in that variable may be error-ridden or endogenous with respect to the amount of cash and bank deposits held by the firm, we estimated the model for different (but nested) instrument sets. Our preferred specification is shown in column 4 . The estimated negative elasticity is 0.08 . With interest rates varying across firms, time dummies are included and the Sargan test improves substantially again. 


\subsection{Conditioning on wage variables}

Finally, we also made attempts to condition on wage variables to allow for the 'shoe-leather cost' effect, as argued for instance in Mulligan (1997), using both measures of wages by economic sectors and firm specific average wages. Time of the firm's manager can be seen as a substitute for large cash holdings and, from this point of view, higher wages may increase cash holdings. Note however that all these measures of wages are poor proxies of the theoretically relevant wages, those of workers involved in the production of transaction services. In all cases the estimated effects were either insignificant or wrong signed.

\subsection{Alternative scale variables}

According to the theoretical model the need for transaction services is created by production. However in the previous empirical analysis we used a measure of firm sales as opposed to an output measure as our scale variable. We now investigate whether annual differences between sales and output might account for the measurement error that we have detected.

In order to do so we tried a constructed measure of output that, among other items, takes into account the change in inventories. The items included in the construction of this output variable are: (i) Sales, (ii) Other operating income, (iii) Change in stocks of finished goods and those in various stages of manufacturing, (iv) Own work capitalised, (v) Change in establishment costs, (vi) Subsidies from private agents, and (vii) Subsidies to products.

The results are unchanged. In particular, the estimates corresponding to Table 3 column 1 using output instead of sales are 0.499 (t-ratio 16.19) for the log output term, -0.028 (t-ratio 5.27) for the interaction of log output with trend, 0.001 (t-ratio 2.20) for the interaction of log output with trend squared, and a p-value for the Sargan test of $5.8 \%$. Those corresponding to Table 3 column 2 are, in the same order, 0.940 (t-ratio 9.54), -0.028 (t-ratio 5.10), 0.001 (t-ratio 1.90), and a p-value for the Sargan test of $48.3 \%$. Clearly the difference between output and sales is not responsible for the measurement error prevailing. This similarity in the results may be due to time aggregation given that sales and output are annual stock measures. We would expect larger discrepancies between output and sales with monthly or quarterly data. 


\section{SOME RESULTS FOR THE UK AND THE US}

In this section we obtain comparable estimates for the US and the UK. We do so in order to check up to what extent measurement error and correlated firm specific effects are also present when estimating money demand equations with firm data for reference countries like the US and the UK. Furthermore, since this turns out to be the case, we provide scale elasticities for the US and the UK when correlated fixed effects and measurement errors are jointly considered.

Our US firm data are taken from Compustat database including all companies listed on the New York Stock Exchange, the American Stock Exchange, or publicly traded. For the UK we use data from Datastream which includes all firms quoted in the UK Stock Exchange. The sample periods are 1978 to 1992 for the US and 1983 to 1997 for the UK. We have chosen sample periods as similar as possible to the CBBE data given the data available to us. Again, due to the estimation methods used, only firms with at least four consecutive observations are kept. We also exclude firms in the banking and financial sector. The number of firm-years left in our sample is 28,859 for the US and 9,672 for the UK, corresponding to 6,772 and 1,572 firms respectively.

The money holdings variable more in line with our CBBE variable in US Compustat is Cash and equivalents ${ }^{21}$. Aside from comparability considerations we think this is the most appropriate definition since all the items included are highly liquid. This is specially true in the US where due to tight credit episodes banks were forced to offer highly liquid alternatives to demand and savings deposits in order to attract funds for which they were not obliged to retain reserve requirements. If only Cash is used important sources of liquidity (government securities and time deposits) are left out. For the UK we use Datastream Total cash and equivalents as our money holdings variable. This also includes highly liquid short-term receivable loans that are excluded from Compustat and CBBE cash and equivalents definitions. Finally, the definition of sales is straightforwardly comparable in the three data sets.

In Table A5 we provide detailed statistics of the distribution of $\log \left(m_{i t} / s_{i t}\right)$ for our three samples. We can see that the distributions for the three countries are very similar, except for the upper tails where in the UK and the US some firms have larger cash holdings with respect to their sales than in Spain.

Our results for the UK and the US are reported in Tables 6 and 7 respectively. In both tables the first three columns report estimates similar to those in Table 1 while

\footnotetext{
${ }^{21}$ In addition to the items in Cash this variable includes: (i) cash in escrow, (ii) clearing house deposits, (iii) government and other marketable securities, (iv) margin deposits on commodity futures contracts, and (v) time, demand and certificate of deposits.
} 
columns 4 to 6 are the equivalent to those in Table 3. As we can see by comparing columns 1 and 6 in Tables 6 and 7, and Table 1 column 2 with Table 3 column 3, the measurement error in levels is very small in the three countries. However correlated firm fixed effects are present in all three cases (compare column 5 to column 6 in Tables 6 and 7, and column 2 to column 3 in Table 3) and need to be taken into account. Once this is done by first-differencing we can see that measurement errors are substantial and around $50 \%$ in all cases.

What turns out to be different is the overall bias due to correlated firm effects. Not taking them into account induces a negative bias for Spain but positive for the US and the UK. If the firm effect $\eta_{i}$ reflect differences in firm financial sophistication (hence corresponding to $-\log H_{i}$ in equation (2.7)), according to the theoretical model they would be negatively correlated with sales. The bias incurred when these correlated firm effects are not taken into account is therefore expected to be negative and this is indeed the case for Spain. However for the UK and the US the bias turned out to be positive. A positive correlation may occur if firm effects are driven by managerial wages since larger firms usually pay higher wages. Moreover high managerial wages, according to the theoretical model, are supposed to increase cash holdings.

The estimates in Tables 6 and 7 column 5 show that over the sample periods considered the scale elasticities in the US and the UK have remained stable, in contrast to Spain. For the UK we estimate this elasticity not to be different from one, similar to the one prevailing in Spain in the mid-1980's. On the other hand for the US, our estimated elasticity of around 0.7 is similar to our estimate for Spain during the mid1990's.

According to the theoretical model, differences in the estimated scale elasticities for the three countries could be thought to reflect differences in the efficiency of their payments systems; for example cheques vs. electronic payments or improvements in the processing of the various forms of payments via an increase in automation. However those differences need not hold for the corresponding aggregates of firms if the degree of representativeness of our samples varies across the three countries.

We also considered a US sample that included the banking and financial sector firms, as in Mulligan (1997,1997b). This produced a distribution of log cash to sales that exhibited a thicker upper tail but the parameters estimates were very similar to those reported (and the same was true for a comparable UK sample). In addition for the US we re-estimated the equations using only Cash (as opposed to Cash and equivalents) as the dependent variable, which provides a closer comparison to Mulligan's results. We tried two different versions including or excluding banking and financial sector firms. In both cases we obtained slightly higher scale elasticities, the 
same sign in biases, but worse results for the test statistics of overidentifying restrictions. 


\section{REFERENCES}

Adao, B. and J. Mata (1999): "Money Demand and Scale Economies: Evidence from a Panel of Firms", mimeo.

Arellano, M. and S.R. Bond (1998): "Dynamic Panel Data Estimation Using DPD98 for Gauss", mimeo.

Arellano, M. and O. Bover (1995): "Another Look at the Instrumental-Variable Estimation of Error-Component Models", Journal of Econometrics, 68, 29-51.

Attanasio, O., Guiso, L., and T. Jappelli (1998): "The Demand for Money, Financial Innovation, ands the Welfare Cost of Inflation: An Analysis with Households Data", mimeo.

Baumol, W.J. (1952): "The Transactions Demand for Cash: An Inventory Theoretic Approach", Quarterly Journal of Economics, 66, 545-556.

Bealy, R., and S.Myers (1996): "Principles of Corporate Finance", $5^{\text {th }}$ edition, McGrawHill.

Cuenca, J.A. (1994): "Variables para el estudio del sector monetario. Agregados monetarios y crediticios, y tipos de interés sintéticos”, Documento de Trabajo no 9416 , Servicio de Estudios, Banco de España.

Estrada, A., García Perea, P., Urtasun, A., and J. Briones (1998): "Indicadores de precios, costes y márgenes en las diversas ramas productivas", Documento de Trabajo no 9801, Servicio de Estudios, Banco de España.

Cabrero, A., Escrivá, J.L., and T.Sastre (1993): "Demand Equations of the New Monetary Aggregates", Estudios Económicos nํ52, Servicio de Estudios, Banco de España.

Faig, M. (1989): "Characterization of the Optimal Tax on Money when it Functions as a Medium of Exchange", Journal of Monetary Economics, 22, 137-148. 
Fenstra, R.C. (1986): "Functional Equivalence between Liquidity Costs and the Utility of Money", Journal of Monetary Economics, 17, 271-291.

Fisher, S. (1974): "Money and the Production Function", Economic Enquiry, 12, 517533.

Friedman, M. (1959): "The Demand for Money: Some Theoretical and Empirical Results", Journal of Political Economy, 67, 327-351.

Fujiki, H. and C.B. Mulligan (1996): "Production, Financial Sophistication, and the Demand for Money by Households and Firms", Bank of Japan Monetary and Economic Studies, July, vol. 14 nำ 1, 65-101.

Griliches, Z. and J.A. Hausman (1986): "Errors in Variables in Panel Data", Journal of Econometrics, 31, 93-118.

Laidler, D.E.W. (1985): "The Demand for Money: Theories, Evidence, and Problems", $3^{\text {rd }}$ edition, Harper and Row, New York.

Lucas, R.E. (1988): "Money Demand in the United States: A Quantitative Review", Carnegie-Rochester Conference Series on Public Policy, 29, 137-168.

McCallum, B. and M.S. Goodfriend (1987): "Demand for Money: Theoretical Studies", in The New Palgrave: a Dictionary of Economics, P. Newman, M. Milgate and J. Eatwell eds., London, Macmillan, 775-781.

Meltzer, A.H. (1963a): "The Demand for Money: A Cross-Section Study of Business Firms", Quarterly Journal of Economics, 77, 405-422.

Meltzer, A.H. (1963b): "The Demand for Money: Evidence from Time Series”, Journal of Political Economy, 71,219-246.

Miller, M.M. and D. Orr (1966): "A Model of the Demand for Money by Firms", Quarterly Journal of Economics, 80, 413-435. 
Mulligan, C.B. (1997): "Scale Economies, the Value of Time, and the Demand for Money: Longitudinal Evidence from Firms", Journal of Political Economy, 105, 10611079.

Mulligan, C.B. (1997b): "The Demand for Money by Firms: Some Additional Empirical Results", Discussion Paper 125, Federal Reserve Bank of Minneapolis.

Mulligan, C.B. and X. Sala-i-Martin (1992): "U.S. Money Demand: Surprising Crosssectional Estimates", Brookings Papers on Economic Activity, 2, 285-343.

Mulligan, C.B. and X. Sala-i-Martin (1996): "Adoption of Fnancial Technologies: Implications for Money Demand and Monetary Policy", CEPR Discussion Paper series ํo 1358.

Pesaran, M.H: and R. Smith (1995): "Estimating Long-Run Relationships from Dynamic Heterogeneous Panels”, Journal of Econometrics, 68, 79-113.

Tobin, J. (1956): "The Interest Elasticity of the Transactions Demand for Money", Review of Economics and Statistics, 38, 241-247.

Vogel, R.C. and G.S. Maddala (1967): "Cross-Section Estimates of Liquid Asset Demand by Manufacturing Corporations", The Journal of Finance, 22, 557-575. 
Table 1: Ordinary Least Squares Estimates.

Sample period 1986-1996 ${ }^{1}$

\begin{tabular}{|c|c|c|c|c|c|c|}
\hline & Levels & Levels & $\begin{array}{c}\text { First } \\
\text { Differences }\end{array}$ & $\begin{array}{c}\text { First } \\
\text { Differences }\end{array}$ & $\begin{array}{l}\text { Orthogonal } \\
\text { Deviations }\end{array}$ & $\begin{array}{l}\text { Orthogonal } \\
\text { Deviations }\end{array}$ \\
\hline Log Sales $_{\text {it }}$ & $\begin{array}{c}0.614 \\
(44.73)\end{array}$ & $\begin{array}{c}0.722 \\
(30.23)\end{array}$ & $\begin{array}{c}0.313 \\
(10.57)\end{array}$ & $\begin{array}{c}0.445 \\
(12.25)\end{array}$ & $\begin{array}{c}0.461 \\
(14.31)\end{array}$ & $\begin{array}{c}0.557 \\
(16.32)\end{array}$ \\
\hline Log Sales $_{\text {it }}{ }^{*}$ Trend & - & $\begin{array}{l}-0.025 \\
(3.18)\end{array}$ & - & $\begin{array}{l}-0.032 \\
(4.87)\end{array}$ & - & $\begin{array}{l}-0.029 \\
(9.65)\end{array}$ \\
\hline Log Sales $_{\text {it }} *$ Trend $^{2}$ & - & $\begin{array}{l}0.001 \\
(1.20)\end{array}$ & - & $\begin{array}{l}0.001 \\
(1.94)\end{array}$ & 一 & $\begin{array}{l}0.002 \\
(6.59)\end{array}$ \\
\hline Year Dummies & yes & yes & yes & yes & yes & yes \\
\hline Industry Dummies & yes & yes & no & no & no & no \\
\hline $\begin{array}{l}\text { Test } 1^{\text {rst }} \text { order serial } \\
\text { correlation }\end{array}$ & 27.90 & 27.97 & -24.63 & -24.70 & -24.65 & -24.76 \\
\hline $\begin{array}{l}\text { Test } 2^{\text {nd }} \text { order serial } \\
\text { correlation }\end{array}$ & 23.10 & 23.18 & -2.39 & -2.51 & -2.41 & -2.56 \\
\hline
\end{tabular}

\section{Notes:}

1. t-ratios in parentheses are robust to heteroskedasticity and serial correlation.

2. Except where the model has been estimated in levels, tests for serial correlation are based on estimates of the residuals in first differences. 
Table 2: The Feedback Model.

GMM estimates using orthogonal deviations; Sample period 1986-1996 ${ }^{1,2}$

\begin{tabular}{|c|c|c|c|c|c|c|}
\hline & $\begin{array}{l}\text { Instruments } \\
\text { in sales } \\
\text { up to t-4 }\end{array}$ & $\begin{array}{l}\text { Instruments } \\
\text { in sales } \\
\text { up to t-2 }\end{array}$ & $\begin{array}{l}\text { Instruments } \\
\text { in sales } \\
\text { up to t-1 }\end{array}$ & $\begin{array}{l}\text { Instruments } \\
\text { in sales } \\
\text { up to } \mathrm{T}\end{array}$ & $\begin{array}{l}\text { 'Anderson- } \\
\text { Hsiao' type } \\
\text { estimator }\end{array}$ & $\begin{array}{c}\text { Uncorrelated } \\
\text { Effects }\end{array}$ \\
\hline Log Sales $_{\text {it }}$ & $\begin{array}{l}0.608 \\
(2.49)\end{array}$ & $\begin{array}{l}0.333 \\
(2.14)\end{array}$ & $\begin{array}{l}0.406 \\
(7.29)\end{array}$ & $\begin{array}{c}0.375 \\
(12.35)\end{array}$ & $\begin{array}{c}0.429 \\
(12.65)\end{array}$ & $\begin{array}{c}0.657 \\
(26.31)\end{array}$ \\
\hline Log Sales $_{\text {it }}{ }^{* T}$ Trend & $\begin{array}{r}-0.042 \\
(4.98)\end{array}$ & $\begin{array}{l}-0.033 \\
(4.56)\end{array}$ & $\begin{array}{l}-0.030 \\
(4.47)\end{array}$ & $\begin{array}{l}-0.031 \\
(6.27)\end{array}$ & $\begin{array}{l}-0.029 \\
(4.46)\end{array}$ & $\begin{array}{l}-0.018 \\
(2.28)\end{array}$ \\
\hline Log Sales $_{\mathrm{it}} *$ Trend $^{2}$ & $\begin{array}{l}0.002 \\
(2.45)\end{array}$ & $\begin{array}{l}0.001 \\
(2.20)\end{array}$ & $\begin{array}{l}0.001 \\
(2.00)\end{array}$ & $\begin{array}{l}0.002 \\
(5.09)\end{array}$ & $\begin{array}{l}0.002 \\
(3.57)\end{array}$ & $\begin{array}{l}-0.000 \\
(0.05)\end{array}$ \\
\hline Year Dummies & yes & yes & yes & yes & yes & yes \\
\hline$\rho_{1}$ & $\begin{array}{c}0.304 \\
(13.10)\end{array}$ & $\begin{array}{c}0.341 \\
(19.64)\end{array}$ & $\begin{array}{c}0.337 \\
(19.75)\end{array}$ & $\begin{array}{c}0.368 \\
(24.17)\end{array}$ & $\begin{array}{c}0.414 \\
(22.68)\end{array}$ & $\begin{array}{c}0.365 \\
(23.34)\end{array}$ \\
\hline$\rho_{2}$ & $\begin{array}{l}0.088 \\
(7.42)\end{array}$ & $\begin{array}{c}0.104 \\
(10.04)\end{array}$ & $\begin{array}{c}0.104 \\
(10.10)\end{array}$ & $\begin{array}{c}0.119 \\
(12.39)\end{array}$ & $\begin{array}{c}0.145 \\
(12.48)\end{array}$ & $\begin{array}{c}0.122 \\
(12.64)\end{array}$ \\
\hline $\begin{array}{l}\text { Test } 1^{\text {rst }} \text { order serial } \\
\text { correlation } \\
\text { Test } 2^{\text {nd }} \text { order serial } \\
\text { correlation }\end{array}$ & -17.96 & $\begin{array}{l}-25.63 \\
-1.28\end{array}$ & -27.40 & -28.90 & $\begin{array}{l}-29.18 \\
-2.46\end{array}$ & $\begin{array}{l}-28.97 \\
-1.93\end{array}$ \\
\hline $\begin{array}{l}\text { Sargan test \% } \\
\text { (p-value) }\end{array}$ & 25.8 & 32.0 & 38.3 & $26.8^{4}$ & just identif. & $3.5^{4}$ \\
\hline $\begin{array}{l}\text { Comfac test \% } \\
\text { (p-value) }\end{array}$ & 64.4 & 29.7 & 11.6 & 0.1 & 0.5 & 0.0 \\
\hline Instruments used & see note 5 & see note 6 & see note 7 & see note 8 & see note 9 & see note 10 \\
\hline
\end{tabular}

\section{Notes:}

1. t-ratios in parentheses robust to heteroskedasticity and serial correlation.

2. Two-step robust estimates.

3. Except where the model has been estimated in levels, tests for serial correlation are based on estimates of the residuals in first differences. In order to compute the Difference Sargan test, note that the value of the Sargan test is 232.54 with 220 degrees of freedom in column 4 and 274.62 with 234 degrees of freedom in column 6.

4. Instruments used in column 1: $\log \mathrm{m}_{\mathrm{i} 1} \ldots \log \mathrm{m}_{\mathrm{it}-2}, \log \mathrm{s}_{\mathrm{i} 1} \ldots \log \mathrm{s}_{\mathrm{it}-4}$, and time dummies. 
5. Instruments used in column 2: $\log \mathrm{m}_{\mathrm{i} 1} \ldots \log \mathrm{m}_{\mathrm{it}-2}, \log \mathrm{s}_{\mathrm{i} 1} \ldots \log \mathrm{s}_{\mathrm{it}-2}$ and time dummies.

6. Instruments used in column 3: $\log \mathrm{m}_{\mathrm{i} 1} \ldots \log \mathrm{m}_{\mathrm{it}-2}, \log \mathrm{s}_{\mathrm{i} 1} \ldots \log \mathrm{s}_{\mathrm{it}-1}$, and time dummies.

7. Instruments used in column 4: $\log \mathrm{m}_{\mathrm{i} 1} \ldots \log \mathrm{m}_{\mathrm{it}-2}, \log \mathrm{s}_{\mathrm{i} 1} \ldots \log \mathrm{s}_{\mathrm{iT}}$, and time dummies.

8. Instruments used in column $5: \log \mathrm{m}_{\mathrm{it}-3}, \log \mathrm{m}_{\mathrm{t}-2}$ both in levels, and the three terms in sales $\left(\log s_{i}, \log s_{i}^{*}\right.$ trend, $\left.\log s^{*} \operatorname{trend}^{2}\right)$ dated $t-2, t-1$, and $t$, in orthogonal deviations.

9. The instruments used in column 6: are those used in column 4 plus log sit for the equations in levels. 
Table 3: The Measurement Error Model.

GMM estimates assuming strictly exogenous sales.

Sample period 1986-1996 ${ }^{1,2}$

\begin{tabular}{|c|c|c|c|}
\hline & $\begin{array}{c}\text { First Differences } \\
\text { No measurement error }\end{array}$ & $\begin{array}{c}\text { First Differences } \\
\text { WN measurement error }\end{array}$ & $\begin{array}{c}\text { Levels } \\
\text { WN measurement error }\end{array}$ \\
\hline Log Sales $_{\text {it }}$ & $\begin{array}{c}0.489 \\
(15.92)\end{array}$ & $\begin{array}{l}0.994 \\
(7.53)\end{array}$ & $\begin{array}{c}0.748 \\
(34.60)\end{array}$ \\
\hline Log Sales ${ }_{\mathrm{it}}{ }^{*}$ Trend & $\begin{array}{l}-0.031 \\
(5.33)\end{array}$ & $\begin{array}{l}-0.031 \\
(4.99)\end{array}$ & $\begin{array}{l}-0.028 \\
(3.97)\end{array}$ \\
\hline Log Sales $_{\mathrm{it}} *$ Trend $^{2}$ & $\begin{array}{l}0.001 \\
(1.98)\end{array}$ & $\begin{array}{l}0.001 \\
(2.30)\end{array}$ & $\begin{array}{l}0.001 \\
(1.40)\end{array}$ \\
\hline Year Dummies & yes & yes & yes \\
\hline Industry Dummies & - & - & yes \\
\hline $\begin{array}{l}\text { Test } 1^{\text {rst }} \text { order serial } \\
\text { correlation } \\
\text { Test } 2^{\text {nd }} \text { order serial } \\
\text { correlation }\end{array}$ & $\begin{array}{l}-24.73 \\
-2.53\end{array}$ & $\begin{array}{l}-24.92 \\
-2.77\end{array}$ & $\begin{array}{l}28.03 \\
23.26\end{array}$ \\
\hline $\begin{array}{l}\text { Sargan test } \% \\
\text { (p-value) }\end{array}$ & 11.8 & 39.4 & 0.0 \\
\hline $\begin{array}{l}\text { Instruments used } \\
\text { (aside from time } \\
\text { dummies) }\end{array}$ & $\log \mathrm{S}_{\mathrm{i} 1}, \ldots \log \mathrm{s}_{\mathrm{iT}}$ & $\begin{array}{l}\log S_{i 1}, \ldots \log s_{i t-2} \\
\log S_{i t+1}, \ldots \log S_{i T}\end{array}$ & $\begin{array}{l}\log s_{i 1}, \ldots \log s_{i t-1} \\
\log s_{i t+1}, \ldots \log s_{i T}\end{array}$ \\
\hline
\end{tabular}

Notes:

1. t-ratios in parentheses robust to heteroskedasticity and serial correlation.

2. Two-step robust estimates. 
Table 4: Summary of Results

\begin{tabular}{|c|c|c|}
\hline Estimation Method & Estimated Scale Elasticity & Diagnostics \\
\hline $\begin{array}{l}\text { 1. OLS with industry and } \\
\text { time fixed effects } \\
\text { Table } 1\end{array}$ & $\begin{array}{c}0.72 \\
(44.7)^{1}\end{array}$ & $\begin{array}{l}\text { - Firm specific effects } \\
\text { - } \quad \text { Serial correlation }\end{array}$ \\
\hline $\begin{array}{l}\text { 2. First differences OLS } \\
\text { Orthogonal deviations OLS } \\
\text { Table } 1\end{array}$ & $\begin{array}{c}0.45 \\
(12.3) \\
\\
0.56 \\
(16.3)\end{array}$ & $\begin{array}{l}\text { Measurement error and/or } \\
\text { non-exogeneity of sales } \\
\text { (feedback) }\end{array}$ \\
\hline $\begin{array}{l}\text { 3. Feedback (comfac) } \\
\text { model allowing for } \\
\text { correlated effects and serial } \\
\text { correlation - GMM } \\
\text { Table } 2 \text { Columns } 1-5 \\
\end{array}$ & $\begin{array}{c}\text { Endog. Sales: } \\
0.33 \\
(2.1)\end{array}$ & $\begin{array}{l}\text { Sales exogenous? } \\
\text { Measurement error? }\end{array}$ \\
\hline $\begin{array}{l}\text { 4. Measurement error } \\
\text { model with exogenous } \\
\text { sales and correlated effects } \\
\text { - GMM } \\
\text { Table } 3 \text { Columns } 1 \text { v. } 2 \\
\end{array}$ & $\begin{array}{l}0.99 \\
(7.5)\end{array}$ & $\begin{array}{l}\text { Measurement errors not } \\
\text { serially correlated }\end{array}$ \\
\hline $\begin{array}{l}\text { 5. Models with } \\
\text { uncorrelated effects - } \\
\text { GMM } \\
\text { Table } 2 \text { Columns } 4 \text { v. } 6 \\
\text { Table } 3 \text { Column } 2 \text { v. } 3 \\
\end{array}$ & $\begin{array}{c}0.66 \\
(26.3) \\
0.75 \\
(34.6)\end{array}$ & Correlated fixed effects \\
\hline $\begin{array}{l}\text { 6. Anderson - Hsiao 'type' } \\
\text { Table } 2 \text { Column } 5\end{array}$ & $\begin{array}{c}0.43 \\
(12.7)\end{array}$ & $\begin{array}{l}\text { GMM is responsible for } \\
\text { some downward bias but } \\
\text { does not explain difference } \\
\text { between static and } \\
\text { feedback models }\end{array}$ \\
\hline
\end{tabular}

Note:

1. t-ratios in parentheses 
Table 5: The Measurement Error Model. Additional Results.

GMM estimates. Sample period 1986-1996 ${ }^{1,2}$.

\begin{tabular}{|c|c|c|c|c|}
\hline & $\begin{array}{c}\text { Basic } \\
\text { Model }^{3} \\
\text { T. } 3 \text { col. } 2\end{array}$ & $\begin{array}{c}\text { M2 } \\
\text { Alternatives } \\
\text { Aggregate } \\
\text { Interest Rate }\end{array}$ & $\begin{array}{c}\text { M2 } \\
\text { Alternatives } \\
\text { Aggregate } \\
\text { Interest Rate }\end{array}$ & $\begin{array}{c}\text { Firm } \\
\text { Specific } \\
\text { Interest Rate }\end{array}$ \\
\hline Log Sales $_{\text {it }}$ & $\begin{array}{l}0.994 \\
(7.53)\end{array}$ & $\begin{array}{l}0.878 \\
(9.55)\end{array}$ & $\begin{array}{l}0.788 \\
(9.41)\end{array}$ & $\begin{array}{l}0.949 \\
(8.96)\end{array}$ \\
\hline Log Sales ${ }_{\text {it }}{ }^{*}$ Trend & $\begin{array}{c}-0.031 \\
(4.99)\end{array}$ & $\begin{array}{l}-0.025 \\
(8.38)\end{array}$ & $\begin{array}{l}-0.025 \\
(8.75)\end{array}$ & $\begin{array}{l}-0.031 \\
(5.42)\end{array}$ \\
\hline Log Sales $_{\mathrm{it}} *$ Trend $^{2}$ & $\begin{array}{l}0.001 \\
(2.30)\end{array}$ & $\begin{array}{l}0.001 \\
(5.21)\end{array}$ & $\begin{array}{l}0.001 \\
(4.95)\end{array}$ & $\begin{array}{l}0.001 \\
(2.43)\end{array}$ \\
\hline Log Interest Rate & - & $\begin{array}{l}-0.281 \\
(5.39)\end{array}$ & $\begin{array}{r}-0.309 \\
(6.14)\end{array}$ & $\begin{array}{l}-0.077 \\
(2.27)\end{array}$ \\
\hline $\begin{array}{l}\text { Log Interest Rate } \\
* \% \text { non-bank debt }\end{array}$ & - & - & $\begin{array}{l}0.066 \\
(4.10)\end{array}$ & - \\
\hline Trend (in the levels) & - & yes & yes & \\
\hline Year Dummies & yes & - & - & yes \\
\hline $\begin{array}{l}\text { Test } 1^{\text {rst }} \text { order serial } \\
\text { correlation } \\
\text { Test } 2^{\text {nd }} \text { order serial } \\
\text { correlation }\end{array}$ & $\begin{array}{l}-24.92 \\
-2.77\end{array}$ & $\begin{array}{l}-24.96 \\
-2.74\end{array}$ & $\begin{array}{l}-24.90 \\
-2.65\end{array}$ & $\begin{array}{l}-24.91 \\
-2.71\end{array}$ \\
\hline $\begin{array}{l}\text { Sargan test \% } \\
\text { (p-value) }\end{array}$ & 39.4 & 0.6 & 3.1 & 50.7 \\
\hline $\begin{array}{l}\text { Instruments used } \\
\text { (aside from time } \\
\text { dummies) }\end{array}$ & $\begin{array}{c}\log s_{i 1, \ldots} \\
\log s_{i t-2} \\
\log s_{i t+1, \ldots} \\
\log s_{i T}\end{array}$ & as in col. 1 & $\begin{array}{l}\text { as in col. } 1 \\
\text { plus } \\
\% \text { non-bank } \\
\text { debt }_{1}, \ldots \\
\% \text { non-bank } \\
\text { debt }_{\mathrm{t}}\end{array}$ & $\begin{array}{c}\text { as in col. } 1 \\
\text { plus } \\
\log _{\mathrm{i} 1}, \ldots \\
\log \mathrm{R}_{\mathrm{it}-2}, \\
\log \mathrm{R}_{\mathrm{it}+1}, \ldots \\
\log \mathrm{R}_{\mathrm{iT}}\end{array}$ \\
\hline
\end{tabular}

Notes:

1. t-ratios in parentheses robust to heteroskedasticity and serial correlation.

2. Two-step robust estimates.

3. First differences, sales strictly exogenous, white noise measurement error. 
Table 6: Results for the UK using Datastream.

Sample period $1986-1997^{1}$

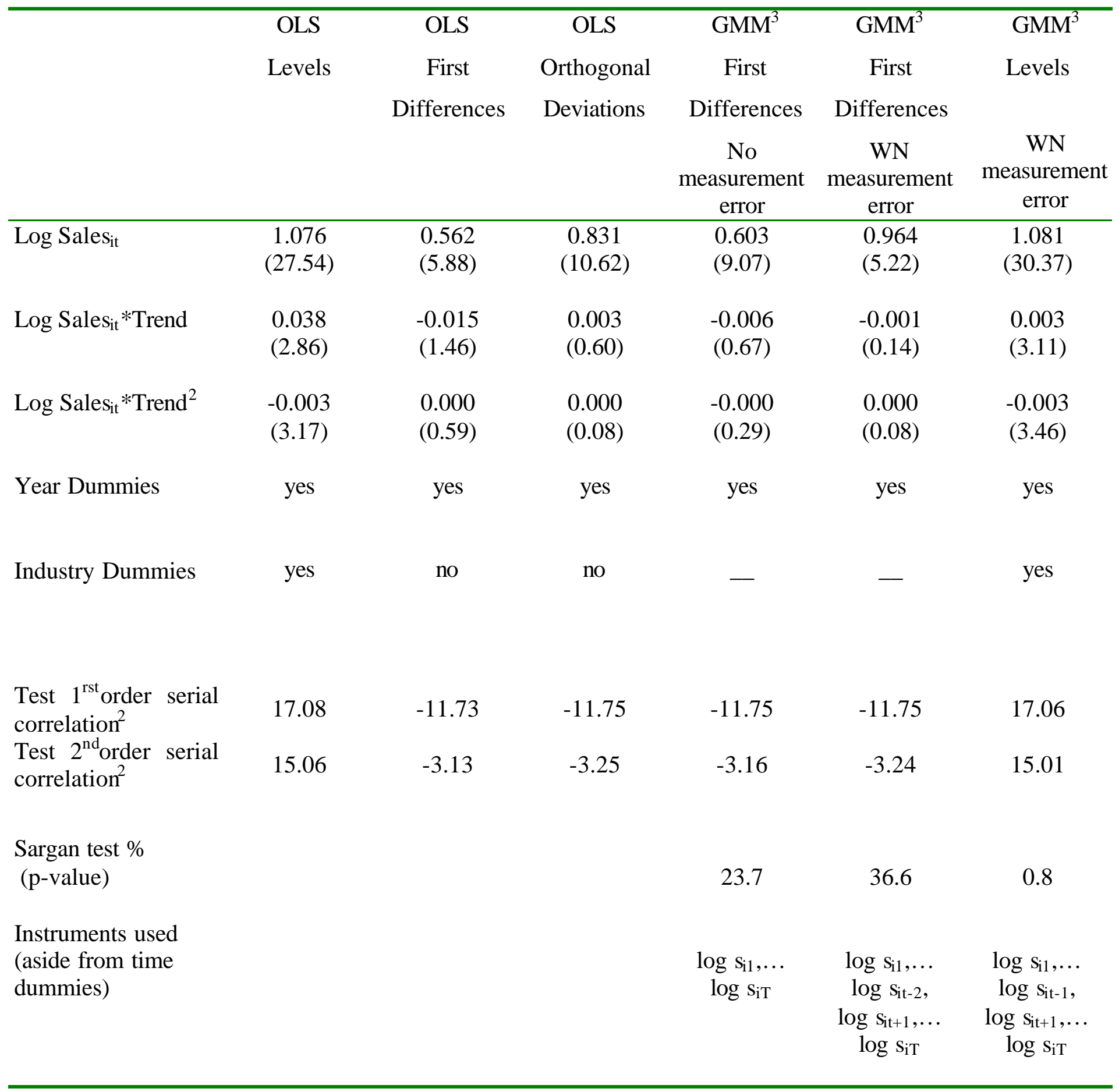

\section{Notes:}

1. t-ratios in parentheses are robust to heteroskedasticity and serial correlation.

2. Except where the model has been estimated in levels, tests for serial correlation are based on estimates of the residuals in first differences.

3. Two-step robust estimates. 
Table 7: Results for the US using Compustat.

Sample period 1981-1992 ${ }^{1}$

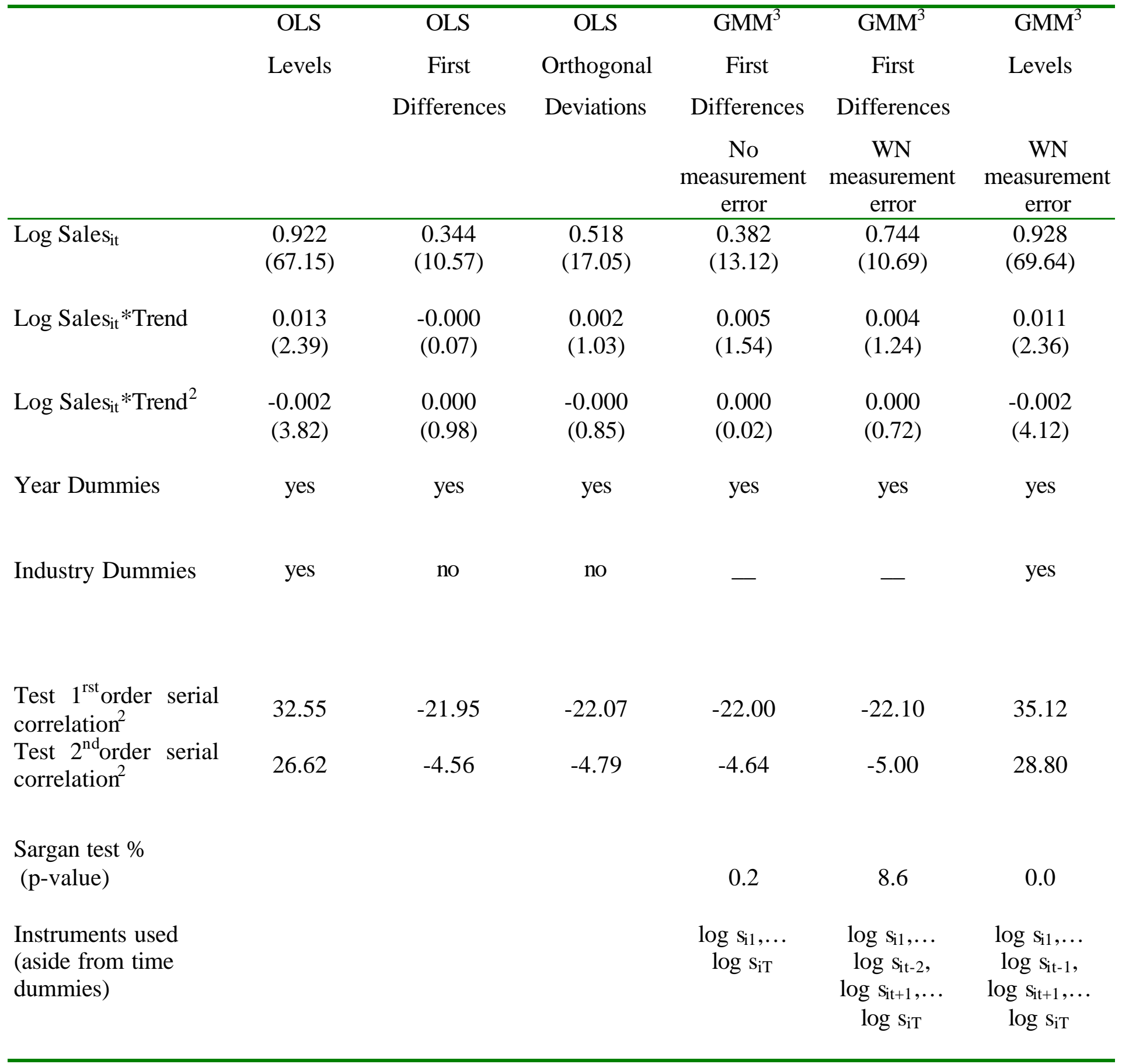

Notes:

1. t-ratios in parentheses are robust to heteroskedasticity and serial correlation.

2. Except where the model has been estimated in levels, tests for serial correlation are based on estimates of the residuals in first differences.

3. Two-step robust estimates. 
Table A.1: Sectoral Composition

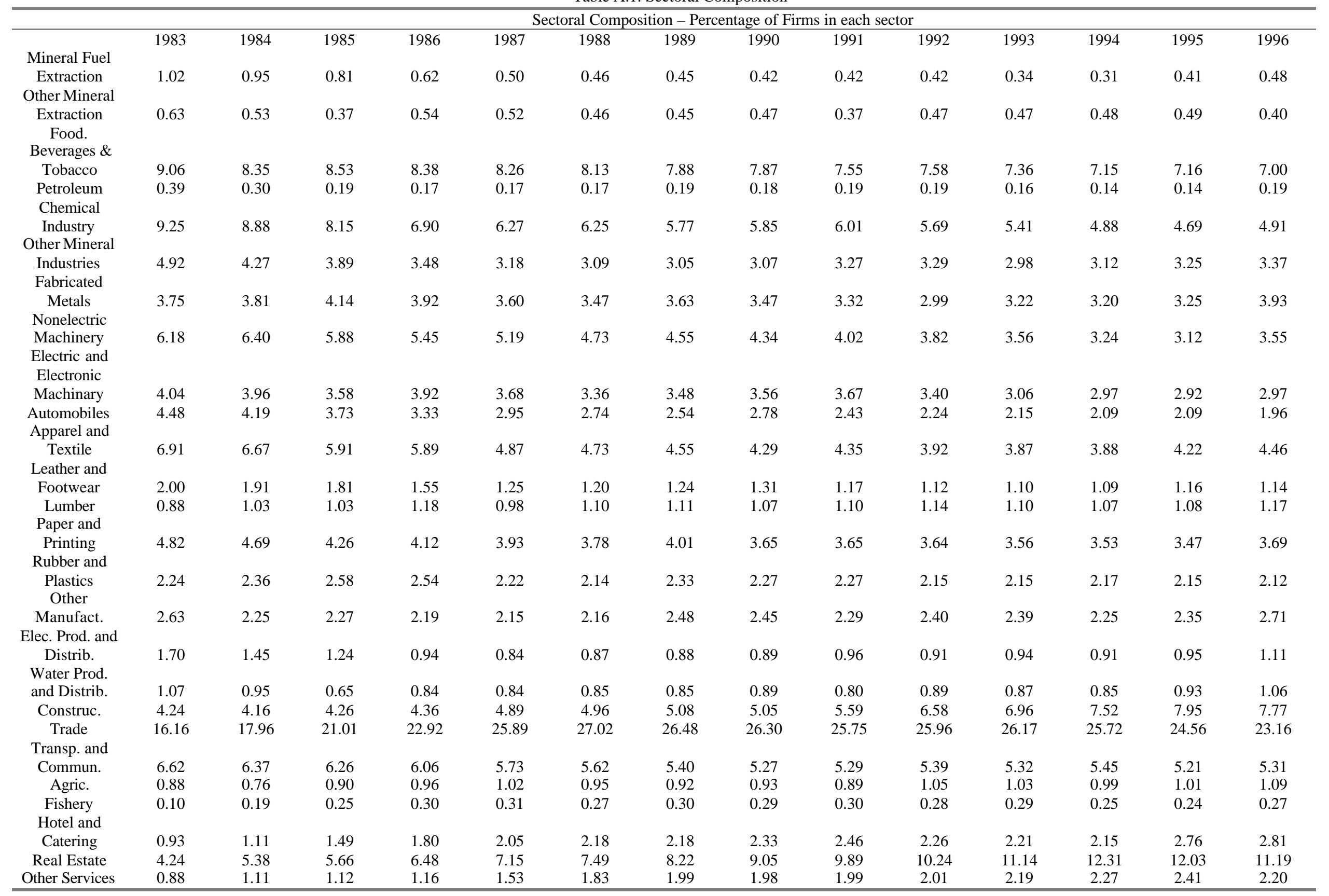


Table A.2: Firms size

\begin{tabular}{lllcccc}
\hline \multicolumn{7}{c}{ Size, by number of employees } \\
\hline & Small & $\%$ & Medium & $\%$ & Large & $\%$ \\
1983 & 1049 & 51 & 697 & 34 & 308 & 15 \\
1984 & 1480 & 56 & 825 & 31 & 319 & 12 \\
1985 & 1947 & 61 & 940 & 29 & 326 & 10 \\
1986 & 2723 & 67 & 1006 & 25 & 328 & 8 \\
1987 & 3397 & 71 & 1044 & 22 & 340 & 7 \\
1988 & 3447 & 72 & 1035 & 21 & 337 & 7 \\
1989 & 3344 & 71 & 996 & 21 & 343 & 7 \\
1990 & 3154 & 70 & 987 & 22 & 357 & 8 \\
1991 & 2990 & 70 & 939 & 22 & 347 & 8 \\
1992 & 3060 & 71 & 888 & 21 & 340 & 8 \\
1993 & 3256 & 73 & 886 & 20 & 328 & 7 \\
1994 & 3661 & 76 & 840 & 17 & 340 & 7 \\
1995 & 3700 & 75 & 895 & 18 & 335 & 7 \\
1996 & 2774 & 74 & 714 & 19 & 282 & 7 \\
\hline
\end{tabular}

Small: total personnel $<100$

Medium: $500<$ total personnel $<=100$

Large: total personnel $>500$

\begin{tabular}{lcccc}
\hline & \multicolumn{3}{c}{ Size, by sales } \\
\hline & Small & $\%$ & Large & $\%$ \\
1983 & 981 & 48 & 1073 & 52 \\
1984 & 1405 & 54 & 1219 & 46 \\
1985 & 1769 & 55 & 1444 & 45 \\
1986 & 2522 & 62 & 1535 & 38 \\
1987 & 3081 & 64 & 1700 & 36 \\
1988 & 3094 & 64 & 1725 & 36 \\
1989 & 2979 & 64 & 1704 & 36 \\
1990 & 2851 & 63 & 1647 & 37 \\
1991 & 2668 & 62 & 1608 & 38 \\
1992 & 2745 & 64 & 1543 & 36 \\
1993 & 2998 & 67 & 1472 & 33 \\
1994 & 3274 & 68 & 1567 & 32 \\
1995 & 3336 & 68 & 1594 & 32 \\
1996 & 2511 & 67 & 1259 & 33 \\
\hline
\end{tabular}

Small: real sales $<1000$

Large: real sales $>=1000$ 
Table A.3: Sample Characteristics

\begin{tabular}{|c|c|c|c|c|c|c|c|c|c|c|}
\hline \multicolumn{11}{|c|}{ Sample Means } \\
\hline & \multicolumn{2}{|c|}{ Real Sales $^{1}$} & \multicolumn{2}{|c|}{ Real Cash $^{\mathrm{I}}$} & \multicolumn{2}{|c|}{ Total Personnel } & \multicolumn{2}{|c|}{ Firm Interest Rate } & \multicolumn{2}{|c|}{$\%$ Nonbank Debt } \\
\hline & Mean & Std. Dev. & Mean & Std. Dev. & Mean & Std. Dev. & Mean & Std. Dev. & Mean & Std. Dev. \\
\hline 1983 & 6730 & 32205 & 260 & 1778 & 521 & 2723 & .417 & 3.27 & .216 & .329 \\
\hline 1984 & 5544 & 29018 & 205 & 1032 & 417 & 2324 & 219 & .945 & 164 & 287 \\
\hline 1985 & 4888 & 27567 & 166 & 761 & 347 & 2034 & .159 & .468 & .166 & .295 \\
\hline 1986 & 3658 & 19001 & 125 & 644 & 286 & 1816 & 145 & 288 & 163 & .300 \\
\hline 1987 & 3417 & 18900 & 100 & 456 & 249 & 1602 & .215 & 1.49 & .181 & .325 \\
\hline 1988 & 3543 & 19483 & 102 & 480 & 247 & 1589 & .369 & 9.77 & .187 & .333 \\
\hline 1989 & 3826 & 21268 & 98 & 525 & 255 & 1652 & .281 & 2.29 & .189 & .337 \\
\hline 1990 & 4036 & 22960 & 87 & 424 & 266 & 1701 & .218 & .623 & .194 & .336 \\
\hline 1991 & 4232 & 25213 & 88 & 426 & 273 & 1761 & 274 & 1.35 & 275 & .365 \\
\hline 1992 & 4161 & 25155 & 78 & 415 & 269 & 1756 & 226 & .925 & .243 & .347 \\
\hline 1993 & 3882 & 23895 & 82 & 523 & 251 & 1670 & .251 & 1.19 & .232 & .347 \\
\hline 1994 & 3911 & 24522 & 79 & 424 & 232 & 1573 & .504 & 19.47 & 218 & .336 \\
\hline 1995 & 3992 & 24817 & 74 & 345 & 230 & 1530 & .215 & 1.09 & .222 & .340 \\
\hline 1996 & 4863 & 29836 & 75 & 322 & 265 & 1721 & .202 & 1.33 & .242 & .353 \\
\hline
\end{tabular}

Note:

1. In 1986 million pesetas 
Table A.4:

Estimated Serial Correlation Matrix- Levels Residuals (Table 1 column 2)

\begin{tabular}{|l|l|l|l|l|l|l|l|l|l|l|}
\hline 1.000 & & & & & & & & & & \\
\hline 0.667 & 1.000 & & & & & & & & & \\
\hline 0.577 & 0.715 & 1.000 & & & & & & & & \\
\hline 0.516 & 0.625 & 0.659 & 1.000 & & & & & & & \\
\hline 0.497 & 0.591 & 0.594 & 0.675 & 1.000 & & & & & & \\
\hline 0.437 & 0.469 & 0.490 & 0.552 & 0.625 & 1.000 & & & & & \\
\hline 0.391 & 0.427 & 0.469 & 0.530 & 0.588 & 0.657 & 1.000 & & & & \\
\hline 0.443 & 0.455 & 0.485 & 0.511 & 0.545 & 0.588 & 0.693 & 1.000 & & & \\
\hline 0.432 & 0.437 & 0.473 & 0.466 & 0.504 & 0.561 & 0.640 & 0.721 & 1.000 & & \\
\hline 0.406 & 0.411 & 0.413 & 0.466 & 0.477 & 0.506 & 0.600 & 0.639 & 0.721 & 1.000 & \\
\hline 0.513 & 0.496 & 0.481 & 0.497 & 0.524 & 0.523 & 0.574 & 0.647 & 0.678 & 0.742 & 1.000 \\
\hline
\end{tabular}


Table A.5:

Sample comparisons of $\log \left(m_{i t} / s_{i t}\right)$ for Spain, the UK, and the US

\begin{tabular}{|c|c|c|c|}
\hline & $\begin{array}{c}\text { Spain, CBBE, } \\
1983-1996\end{array}$ & $\begin{array}{c}\text { UK, Datastream, } \\
1983-1997\end{array}$ & $\begin{array}{c}\text { US, Compustat, } \\
1978-1992\end{array}$ \\
\hline Mean & -3.812 & -3.543 & -3.244 \\
\hline Standard Deviation & 1.494 & 2.111 & 1.641 \\
\hline $5^{\text {th }}$ percentile & -6.558 & -8.025 & -5.863 \\
\hline $10^{\text {th }}$ percentile & -5.759 & -6.726 & -5.239 \\
\hline $25^{\text {th }}$ percentile & -4.600 & -4.510 & -4.323 \\
\hline $50^{\text {th }}$ percentile & -3.638 & -3.105 & -3.227 \\
\hline $75^{\text {th }}$ percentile & -2.847 & -2.146 & -2.115 \\
\hline $90^{\text {th }}$ percentile & -2.188 & -1.391 & -1.230 \\
\hline $95^{\text {th }}$ percentile & -1.754 & -0.856 & -0.686 \\
\hline
\end{tabular}

